\title{
Evaluation of Productive and Reproductive Performance of Cattle in Major Dairy Production Area of Chitwan and Nawalparasi Districts
}

\author{
Uddhav Paneru $^{1}$, Mohan Sharma ${ }^{2}$, Mana Raj Kolachhapati ${ }^{2}$ and Bhola Shanker Shrestha ${ }^{3}$ \\ 1. Nepal Agricultural Research Council, Regional Agricultural Research Station, Lumle 33711, Nepal \\ 2. Agriculture and Forestry University, Rampur 44209, Nepal \\ 3. Nepal Agricultural Research Station, Khumaltar 44703, Nepal
}

\begin{abstract}
A study was conducted to determine the productive and reproductive performance of dairy cattle reared in major milk production area of Chitwan and Nawalparasi districts of Nepal, as well as determining the existing breeding scenario of cattle farming followed by the farmers. Five years (2008-2012) of data of 728 animals send to data management section of Animal Breeding Division under Dairy Cattle Improvement Program (DCIP) were reviewed and analyzed. Similarly, monthly data recording of 380 animals taken from May 2012 to April 2013 were used to find out information on reproductive performance. Average milk yield, fat percentage and protein percentage of cattle were observed $2,841 \pm 84.9 \mathrm{~kg}, 4.43 \% \pm 0.66 \%$ and $3.33 \% \pm 0.17 \%$, respectively, and the effect of genotype on these traits were found significant $(P<0.001, P<0.001$ and $P<0.01$, respectively). Similarly, calving interval, post-partum estrus, post-partum conception, age at maturity and age at first calving were observed 422.8 $\pm 7.71,108.9 \pm 6.13,149.93 \pm 27.04,498.5 \pm 16.32$ and $816.0 \pm 17.41 \mathrm{~d}$, respectively. Age at maturity and age at first calving was significantly affected by genotype $(P<0.01$ and $P<0.05$, respectively). In addition, average number of insemination per conception was observed 1.38 in survey household. Breeding system of cattle followed by the farmers were found satisfactory in the survey household, but needs gradual improvement. It was observed that offspring of cross between Jersey and Holstein performed better in terms of productive and reproductive performance in farmer managed condition of Nepal. Therefore, rotational crossing of Jersey and Holstein for maintaining blood level between $50 \%$ and $75 \%$ of either breed is the best choice for farmers.
\end{abstract}

Key words: Calving interval, post-partum estrus, rotational crossing, blood level.

\section{Introduction}

Livestock is integral component of Nepalese agriculture, contributing $8 \%$ of total gross domestic product (GDP) and $25.68 \%$ of agricultural gross domestic product (AGDP). Total milk production in the country is $1,700,073$ metric tons, of which $31 \%$ is contributed by cattle and the rest by buffalo [1]. In recent days, dairy farming is starting at commercial scale, and is quiet popular agribusiness of Nepal. It is believed that one off farm job is created, when 10-20 $\mathrm{L}$ of milk entered in processing and marketing chain [2]. In the context of agrarian country, like Nepal,

Corresponding author: Uddhav Paneru, M.Sc., research field: animal breeding. dairy sector is backbone of rural economy and one of the major sources of flow of money from urban city to village. On the other hand, dairy sector has huge chances of growth due to high demand of milk in major cities because of urbanization and migration. However, production and productivity of cattle in Nepal is very low with 519.56 L per lactation [3] and needs lots of improvement. There is a large variation of productive and reproductive performance of cattle in Nepal. In the authors' records, it was found cattle gave 5,800 L of milk per lactation, but its performance is not exploited to increase overall herd average of Nepalese cattle.

To make dairy sectors more competitive and commercial, there is need to increase productive and 
reproductive performance of cattle. Efforts of crossbreeding of local cattle with exotic breed were done time and again to increase the performance of cattle. But, improvements over years are not accessed in proper manner. Farmers use exotic germ plasma recklessly without knowing which breed is appropriate for upgrading in the context. Till date, only few researches were done in dairy sector in Nepal. Thus, this research aimed to find out the productive and reproductive performance of Nepalese cattle in large scale as a benchmark of productive performance, as well as the most appropriate germ plasma for improvement of native cattle. In addition, research also planed to find out the most appropriate exotic germ plasma and extent of crossbreeding suitable for improvement of cattle at farmers managed condition of Nepal.

\section{Materials and Methods}

This study was conducted in major dairy production area of Chitwan and Nawalparasi districts. Data were collected from the animals registered in Pedigree and Performance Recording System (PPRS) under Dairy Cattle Improvement Program (DCIP). Five years of data between 2008 and 2012 were reviewed. Those animals in the records were divided into the following categories based on the blood level (Table 1), though some part of native blood is present in every group.

The general practice of PPRS is that from each animal, milk was collected at month interval at morning and evening, and kept in the sample vile of $50 \mathrm{~mL}$. In addition, total milk produced by the cow was also measured, including the milk that is needed for suckling of calf. The milk collected from this procedure was taken to District Livestock Service Office (DLSO) for examination of different milk constituents. Different constituents in the milk, such as milk fat percentage, milk protein percentage and conductivity, were measured with the help of LM2 model milk analyzer of Milkotester company. Animals, which have eight or more than eight test day, milk yield representing true value of lactation yield, thus were only taken for analysis and the rest are discarded. In addition, data were also recorded at monthly interval from May 2012 to April 2013 to find out information on reproductive performance. Thirty household in each district were surveyed to find out information on existing breeding system.

Parameters taken for productive performance were lactation milk yield (kg), fat percentage (\%) and protein percentage (\%). Parameters taken for reproductive performance were age at first heat, calving interval, post-partum estrus and number of insemination per conception.

Data were entered in Microsoft access and analyzed by $\mathrm{R}$ software package of statistical computing. The mean comparisons were done using duncan multiple range test (DMRT) for every factors, and different subscripts were assigned to mean with significant difference in same column. Mean differences were tested in different probability level and assigned asterisk sign based on significant level. In addition, data on household survey were entered in SPSS and analyzed by the same software package.

\section{Result and Discussion}

\subsection{Productive Performance}

Productive performance of dairy cattle and value of

Table 1 Categorization of breed based on blood level.

\begin{tabular}{ll}
\hline Breed & Blood level \\
\hline Jersey & Having at least $75 \%$ of the blood level of Jersey breed \\
Holstein & Having at least $75 \%$ of the blood level of Holstein breed \\
Jersey $\times$ Holstein & Cross of Jersey and Holstein breed with $37 \%$ blood level of either breed \\
$50 \%$ Jersey & Having at least $50 \%$ of the blood level of Jersey breed \\
$50 \%$ Holstein & Having at least $50 \%$ of the blood level of Holstein breed \\
Other breed & Having unknown ancestry and mixed breed \\
\hline
\end{tabular}


different milk constituents were presented in Table 2. The overall mean of lactation milk yield of cattle observed in this study was $2,841 \pm 84.95 \mathrm{~kg}$. The results of this study revealed that the milk yield was significantly $(P<0.001)$ affected by the breeds.

Accordingly, the highest milk production 3,173 \pm $55.2 \mathrm{~kg}$ was observed in Holstein cattle among the different breeds, followed by cross between Jersey and Holstein (2,948 $\pm 54.4 \mathrm{~kg})$. In addition, overall mean of fat percentage of cattle observed was $4.43 \% \pm$ $0.66 \%$. In a similar study in India, fat percentage in milk of HF, Jersey, Brown Swiss, Sahiwal and crossbred cows were $3.3 \%-4.1 \%, 4.9 \%-5.5 \%$, $3.6 \%-4.1 \%$, $4.6 \%$ and $4.4 \%$, respectively [4]. The results of this study revealed that fat percentage was significantly affected $(P<0.001)$ by genotype. Similarly, protein percentage of cattle was $3.33 \% \pm$ $0.17 \%$, and the effect of genetic group on protein percent was also found significant $(P<0.001)$. Holstein has higher protein percentage than other cattle. Similar finding for average protein percentage content in milk of cow in Mongolia, Myanmar and Nepal were found $3.47 \%, 3.41 \%$ and $3.31 \%$, respectively [5]. Feritas et al. [6] reported that protein percentage in milk of cows was $2.88 \% \pm 0.34 \%$ to $2.85 \% \pm 0.33 \%$. The popularity of crossbreeding in New Zealand is attributed to high productivity in pasture-based systems [7], superior reproductive performance, [8] longer survival [9] and consequential benefits in terms of profit [10]. Consequently, crossbred cows (Jersey $\times$ Holstein Friesian; F1) now account for a significant proportion (33\%) of the national herd in New Zealand [11]. In New Zealand and North American, Holstein has increased from 2\% to $38 \%$ in recent years to increase the genetic base of Holstein Friesian population. The Northern hemisphere Holstein Friesian genotype is capable of very high milk yields, but on pasture alone mobilises large amounts of body reserves, which reduces lactation length and reproductive performance [12, 13]. Crossbreeding was adopted to reduce the impact of "Holsteinisation" [12] Farmers focused on breeding cows more suited to pasture-based systems [14] and also took advantage of heterosis effects, including the benefit for fertility [15].

The genetic correlation between milk yield and various milk constituents is presented in Table 3. Highly positive correlation (0.93) was observed between lactation milk yield and valuable solid. Whereas, negative correlation (-0.13) was observed between lactation milk yield and fat percentage, and also negative correlation $(-0.25)$ between lactation milk yield and protein percentage. Slightly positive correlation was observed between valuable solid and fat

Table 2 Effect of genetic group on lactation milk yield, protein percentage and fat percentage of dairy cattle.

\begin{tabular}{|c|c|c|c|c|}
\hline \multirow{2}{*}{ Breed } & \multirow{2}{*}{$\begin{array}{l}\text { No. of } \\
\text { observation }\end{array}$} & Milk yield (kg) & Protein percentage (\%) & Fat percentage (\%) \\
\hline & & \multicolumn{3}{|c|}{ Least square mean } \\
\hline Jersey & 327 & $2,735 \pm 38.7^{\mathrm{c}}$ & $3.31 \pm 0.009^{c}$ & $4.46 \pm 0.34^{\mathrm{a}}$ \\
\hline Holstein & 165 & $3,173 \pm 55.2^{\mathrm{a}}$ & $3.33 \pm 0.016^{\mathrm{a}}$ & $4.21 \pm 0.06^{\mathrm{b}}$ \\
\hline Jersey $\times$ Holstein & 122 & $2,948 \pm 54.4^{\mathrm{b}}$ & $3.28 \pm 0.013^{\mathrm{d}}$ & $4.54 \pm 0.05^{\mathrm{a}}$ \\
\hline $50 \%$ Jersey & 61 & $2,631 \pm 89.5^{\mathrm{c}}$ & $3.32 \pm 0.020^{\mathrm{bc}}$ & $4.51 \pm 0.08^{\mathrm{a}}$ \\
\hline $50 \%$ Holstein & 25 & $2,849 \pm 139.8^{b}$ & $3.22 \pm 0.037^{\mathrm{e}}$ & $4.22 \pm 0.13^{\mathrm{b}}$ \\
\hline Other breeds & 28 & $2,711 \pm 132.1^{\mathrm{c}}$ & $3.34 \pm 0.028^{\mathrm{b}}$ & $4.51 \pm 0.13^{\mathrm{a}}$ \\
\hline Overall mean & 728 & $2,841 \pm 84.95$ & $3.33 \pm 0.17$ & $4.43 \pm 0.66$ \\
\hline Level of significance & & $* * *$ & $* *$ & $* * *$ \\
\hline CV (\%) & & 24.50 & 5.20 & 14.90 \\
\hline
\end{tabular}


Table 3 Correlation of lactation milk yield with various milk constituents.

\begin{tabular}{lllll}
\hline Parameters & Milk yield $(\mathrm{kg})$ & Fat percentage (\%) & Protein percentage (\%) & Valuable solid $(\mathrm{kg})$ \\
\hline Milk yield (kg) & 1.00 & -0.13 & -0.25 & 0.93 \\
Fat percentage (\%) & -0.13 & 1.00 & 0.07 & 0.21 \\
Protein percentage (\%) & -0.25 & 0.07 & 1.00 & -0.15 \\
Valuable solid (kg) & 0.93 & 0.21 & -0.15 & 1.00 \\
\hline
\end{tabular}

Table 4 Effect of genetic group on reproductive performance of dairy cattle.

\begin{tabular}{|c|c|c|c|c|}
\hline \multirow{2}{*}{ Breed } & \multirow{2}{*}{$\begin{array}{l}\text { No. of } \\
\text { observation }\end{array}$} & Calving interval (d) & Postpartum estrus (d) & Postpartum conception (d) \\
\hline & & \multicolumn{3}{|c|}{ Least square mean } \\
\hline \multicolumn{5}{|l|}{ Breed effect } \\
\hline Jersey & 110 & $420.30 \pm 10.66$ & $107.00 \pm 8.6$ & $135.20 \pm 10.45^{b}$ \\
\hline Holstein & 45 & $429.70 \pm 20.73$ & $106.10 \pm 13.08$ & $138.20 \pm 20.15^{\mathrm{b}}$ \\
\hline Jersey $\times$ Holstein & 35 & $379.40 \pm 14.08$ & $85.73 \pm 14.29$ & $89.45 \pm 13.97^{\mathrm{a}}$ \\
\hline $50 \%$ Jersey & 20 & $480.00 \pm 81.80$ & $120.50 \pm 21.78$ & $216.50 \pm 73.30^{\mathrm{d}}$ \\
\hline $50 \%$ Holstein & 31 & $437.40 \pm 14.19$ & $128.32 \pm 15.49$ & $170.32 \pm 19.30^{\mathrm{c}}$ \\
\hline Level of significant & & NS & NS & $*$ \\
\hline \multicolumn{5}{|l|}{ Season effect } \\
\hline Summer & 55 & $401.35 \pm 16.22^{\mathrm{a}}$ & $97.00 \pm 12.95$ & $112.97 \pm 16.26$ \\
\hline Winter & 51 & $467.03 \pm 17.26^{\mathrm{b}}$ & $145.20 \pm 13.79$ & $183.93 \pm 17.31$ \\
\hline Spring & 59 & $433.29 \pm 15.34^{\mathrm{ab}}$ & $111.60 \pm 12.25$ & $158.21 \pm 15.38$ \\
\hline Autumn & 76 & $405.37 \pm 12.87^{\mathrm{a}}$ & $94.87 \pm 10.28$ & $120.15 \pm 12.90$ \\
\hline Level of significance & & $*$ & NS & NS \\
\hline Overall mean & 250 & $422.80 \pm 7.71$ & $108.90 \pm 6.13$ & $149.93 \pm 27.04$ \\
\hline CV (\%) & & 22.04 & 13.71 & 12.86 \\
\hline
\end{tabular}

*** represent mean is significant at $5 \%$ probability level $(P<0.05)$; NS: not statistically significant.

${ }^{\mathrm{a}-\mathrm{d}}$ means with different subscripts in the same column differ significantly; values sharing at least one subscript in the same column differ not significantly.

percentage (0.21), and between protein percentage and fat percentage (0.07). Low negative correlation between milk yield and fat percent in case of Nepalese cattle suggested that more selection towards milk yield can be done with less compromise on fat percentage. This might be due to the low selection intensity adopted towards the cattle as well as due to the inheritance of indigenous germ plasma. Research initiated by Farthing and Legates [16] reported higher negative correlation between milk yield and fat percentage to be 0.38; similarly, Tabler and Touchbery [17] reported it to be 0.33 . Study based in Illinois herd of USA reported higher negative correlation of -0.44 between milk and fat percentage in Holstein and Guernseys breeds of cattle [18].

\subsection{Reproductive Performance}

The different reproductive parameters of cattle were presented in Table 4. The overall mean of calving interval, postpartum estrus and postpartum conception of cattle was found $422.8 \pm 7.71,108.9 \pm 6.13$ and $149.93 \pm 27.04 \mathrm{~d}$, respectively. The lowest calving interval, postpartum estrus and postpartum conception were found $379.4 \pm 14.08,85.73 \pm 14.29$ and $89.45 \pm$ $13.97 \mathrm{~d}$, respectively, in cross between Jersey and Holstein. Efficient reproductive performance of Jersey crossing with Holstein might be due to inheriting capacity of Jersey and Holstein breed as well as heterosis in its offspring. It has been shown in previous studies that well-nourished temperate heifer has the potential to reach the specific weight (2/3 body weight) at 10-12 months, and conceived earlier at 14-15 months of age [19, 20]. Sattar et al. [21] observed calving interval of Jersey breed $430.15 \pm$ $4.87 \mathrm{~d}$, ranging from $319 \mathrm{~d}$ to $878 \mathrm{~d}$ in Pakistan. In a similar study, calving interval of $13.8 \pm 0.4$ months in case of cross between Jersey and non-descript breed of cattle in Nepal was observed by Shrestha and 

Dairy Production Area of Chitwan and Nawalparasi Districts

Sherchand [22]. Kollalpitiya et al. [23] observed the lowest calving interval of $403 \mathrm{~d}$ for Jersey breed in Sri Lanka. Rafique et al. [24] reported the almost similar findings in crossbred cows in Pakistan. In a study in walaita soda dairy farm, Euthopia, it was found significant effect of season of calving on calving interval of the breed [25].

The overall mean of age at maturity of the cattle were observed $498.5 \pm 16.32 \mathrm{~d}$ (Table 5). The lowest mean ( $434.7 \pm 46.08 \mathrm{~d})$ at maturity of the cattle were observed in cross between Jersey and Holstein, whereas the maximum age $(965.2 \pm 70.44 \mathrm{~d})$ at first maturity were observed in 50\% Holstein. Accordingly, the overall mean of age at first calving of the breed for this study was observed $816.0 \pm 17.41 \mathrm{~d}$ (Table 5). The results of this study revealed that the age at first conception was significantly affected by the genotype $(P<0.05)$. Age at first calving was observed short $784 \pm 18.78 \mathrm{~d}$ for Jersey cattle, followed by cross between Jersey and Holstein $795.1 \pm 78.66 \mathrm{~d}$. Rokonuzzaman et al. [26] found significant effect of breed $(P<0.01)$ on age at first calving of crossbreed cattle in Bangladesh, and found the shortest age at calving of 34.12 month in Friesian and indigenous crosses. In a similar study in Punjab of Pakistan, the significant effect of breed $(P<0.05)$ on age at first calving was reported [27]. A lower value of age at first puberty of Jersey cattle $748.71 \pm 22.5 \mathrm{~d}$ than present finding in Harichand, Charsadda, NWFP was reported [28]. This finding was in agreement with age at first calving of $772 \mathrm{~d}$ for Jersey heifers in Punjab of Pakistan [29].

The overall mean of the number of insemination per cattle was observed $1.38 \pm 0.60$ (Table 6). The results of the above study revealed that the genotype has no significant effect $(P>0.05)$ on number of insemination in cattle. Accordingly, frequency of insemination required for conception of the cow was found low for the breed of cross between Jersey and Holstein, while high frequency of insemination per cattle was recorded in 50\% Jersey. Genotype plays a significant $(P<0.001)$ role in service per conception

Table 5 Effect of breed on age at maturity of dairy cattle.

\begin{tabular}{llll}
\hline Breed & No. of observation & Mean age of maturity (d) & Age at first calving (d) \\
\hline Jersey & 65 & $470.60 \pm 17.75^{\mathrm{b}}$ & $784.00 \pm 18.78^{\mathrm{a}}$ \\
Holstein & 23 & $558.00 \pm 38.68^{\mathrm{c}}$ & $866.00 \pm 38.66^{\mathrm{b}}$ \\
Jersey $\times$ Holstein & 20 & $434.70 \pm 46.08^{\mathrm{a}}$ & $795.10 \pm 78.66^{\mathrm{a}}$ \\
$50 \%$ Jersey & 10 & $587.50 \pm 47.50^{\mathrm{c}}$ & $925.00 \pm 10.00^{\mathrm{c}}$ \\
$50 \%$ Holstein & 12 & $657.30 \pm 76.83^{\mathrm{d}}$ & $965.20 \pm 70.44^{\mathrm{cd}}$ \\
\hline Overall & 130 & $498.50 \pm 16.32$ & $816.00 \pm 17.41$ \\
\hline Level of significance & & $* *$ & $*$ \\
\hline CV $(\%)$ & 25.40 & 17.37 \\
\hline
\end{tabular}

** represent means significant at $1 \%$ probability level $(P<0.01)$; * represent means significant at 5\% probability level $(P<0.05)$;

${ }^{\mathrm{a}-\mathrm{d}}$ means with different subscripts in the same column are significantly different.

Table 6 Effect of breed on number of insemination of cattle.

\begin{tabular}{lll}
\hline Genotype & No of observation & No. of insemination \\
\hline Jersey & 139 & $1.38 \pm 0.051$ \\
Holstein & 33 & $1.24 \pm 0.097$ \\
Jersey $\times$ Holstein & 18 & $1.22 \pm 0.101$ \\
$50 \%$ Jersey & 6 & $1.66 \pm 0.33$ \\
$50 \%$ Holstein & 31 & $1.41 \pm 0.12$ \\
\hline Overall & 222 & $1.38 \pm 0.60$ \\
\hline Level of significance & & NS \\
\hline CV $(\%)$ & & 20.30 \\
\hline
\end{tabular}

NS: not significant. 
was recorded in Ireland [30]. In the same study, it was observed that number of service per conception to be 1.69, 2.11 and 2.44 for Jersey $\times$ Holstein, Holstein and Jersey breed of cattle, respectively. Almost similar finding of 1.50 and 1.80 for frequency of insemination was recorded by Mangurkar et al. [31] and Garcia and Velez [32], respectively. Rokonuzzaman et al. [26] found number of service per conception of 1.84 in crossbreed Holstein $\times$ Friesain and local cattle in Bangladesh. Haque et al. [33] observed slightly lower frequency of insemination per conception of $1.09 \pm$ 0.06 in cross of Jerey and Holstein in first parity in Sylhet government dairy farm of Bangladesh.

\subsection{Existing Breeding System Followed by the Farmers}

Almost all herds were selected for pedigree and performance recording, so, breeding system followed by farmers was found satisfactory in survey household. In the context of breeding, farmers were familiar with high milk yielding breeds of abroad country, artificial insemination and conscious with quality of sire used for artificial insemination. Some of the farmers have started using sex sorted semen for their animals with the support of dairy cattle improvement program. In addition, most of the farmers were conscious with age at maturity of cattle, scape of one heat in early period of estrus in their heifers. However, farmers have very poor recording system for selection of their animals, planning of feed ingredients for their animals and flushing of feed ingredients before breeding. As far as health facility is concerned, farmers do have very little facilities in improving infertility problems by veterinary surgeon. Problems of heat stress and other infectious reproductive disease are gaining momentum with the increment of milk yield in cattle.

\section{Conclusions}

There is high variability in productive and reproductive performance cattle in the country. The productive capacity of breed can be increased by selection and adoption of suitable mating system. Upgrading cattle with high grade sire from developed nation is the best measures to increase productivity of Nepal native breed in short period of time. In designing mating system, crossbreeding of Jersey with Holstein by maintaining at least $37.5 \%$ of either breed is best suited to farmers in managed condition of subtropical climate of Nepal. Hence, crossbreed cow of Jersey and Holstein with very few percentage of blood level of local cattle is recommended for farmers.

\section{References}

[1] Ministry of Agricultural Development (MoAD). 2014. "Statistical Information of Nepalese Agriculture 2013/2014.” Government of Nepal, Agri-Business Promotion and Statistical Division, Ministry of Agricultural Development, Singha Durbar, Kathmandu, Nepal. Accessed March 10, 1015. http://www.moad.gov.np/uploads/files/Year\%20book\%2 02014.pdf.

[2] Food and Agriculture Organization of the United Nations. 2010. "Dairy Sectors Study of Nepal.” FAO. Accessed April 9, 2015. ftp://ftp.fao.org/TC/CPF/Country\%20 NMTPF/Nepal/thematic\%20studies/Dairy.pdf.

[3] Ministry of Agricultural Development (MoAD). 2015. "Statistical Information of Nepalese Agriculture 2014/2015.” Government of Nepal, Agri-Business Promotion and Statistical Division, Ministry of Agricultural Development, Singha Durbar, Kathmandu, Nepal. Accessed April 5, 2016. http://www.moad.gov.np/uploads/files/Year\%20book\%2 02015.pdf.

[4] Sastry, N. S. R. 1997. Genetic Improvement of Cattle, Buffalo and Small Ruminants in India: Requirements and Past Experiences. Breeding Programs for Ruminants in Asia, March 32-April 4, 1997, Kandalama (Matale), Sri Lanka.

[5] Wagner, H. G. 2010. "Experience from the Implementation of Three TCPs on Genetic Improvement.” Presented at Final Workshop on Genetic Improvement in APHCA Countries, May 21, 2010, Sauraha, Chitwan, Nepal.

[6] Freitas, A. F., Milagres, J. C., Teixeira, N. M., and Castro, A. C. G. 1991. "Milk Production in Mixed Dairy Herd." Rev. Soc. Bras. Zootec. 20: 80-9.

[7] Penno, J. W. 1998. "Principles of Profitable Dairying.” In Proceedings of the Ruakura Farmers' Conference, 1-14.

[8] Auldist, M. J., O’Brien, G., Cole, D., Macmillan, K. L., 

Dairy Production Area of Chitwan and Nawalparasi Districts

and Grainger, C. 2007. "Effects of Varying Lactation Length on Milk Production Capacity of Cows in Pasture-Based Dairying Systems.” J. Dairy Sci. 90: 3234-41.

[9] Harris, B. L., Holmes, C. W., Winkelman, A. M., and Xu, Z. Z. 1999. "Comparisons between Fertility and Survival of Strains of Holstein Friesian Heifers, Jersey Heifers and Their Crosses in New Zealand.” In Fertility in the High Producing Dairy Heifer. Galway, Ireland: British Society of Animal Science.

[10] Lopez-Villalobos, N., Garrick, D. J., Holmes, C. W., Blair, H. T., and Spelman, R. J. 2000. "Profitability of Some Mating Systems for Dairy Herds in New Zealand.” J. Dairy Sci. 83: 144-53.

[11] Livestock Improvement Corporation (LIC). 2003. Dairy Statistics of New Zealand.

[12] Harris, B. L., and Kolver, E. S. 2001. "Review of Holsteinization on Intensive Pastoral Dairy Farming in New Zealand.” Journal of Dairy Science 84: E56-E61.

[13] Harris, B. L., and Winkelman, A. M. 2000. "Influence of North American Holstein Genetics on Dairy Cattle Performance in New Zealand.” In Proceedings of the Large Herds Australia Conference, 122-36.

[14] Montgomerie, W. A. 2004. "Future Genetic Progress of Dairy Cattle in New Zealand.” Proceedings of the New Zealand Society of Animal Production 64: 96-100.

[15] Harris, B. L. 2005: Breeding Dairy Cows for the Future in New Zealand." New Zealand Veterinary Journal 53: 384-9.

[16] Farthing, B. R., and Legates, J. E. 1957. "Genetic Covariation between Milk Yield and Fat Percentage in Dairy Cattle.” J. Dairy Sci. 40 (6): 639-46.

[17] Tabler, K. A., and Touchbery, R. W. 1959. "Selection Indices for Milk and Fat Yield of Holstein-Friesian Dairy Cattle.” J. Dairy Sci. 42 (1): 123-6.

[18] Batra, T. R., Norton, H. W., and Touchberry, R. W. 1969. "Genetic Study Milk Constituents in Purebreed and Crossbred Dairy Cattle.” J. Anim. Sci. 29 (5): 671-7.

[19] Hafez, E. S. E., and Hafez, B. 2000. Reproduction in Farm Animals, 7th ed.. Philadelphia, USA: Lea and Febiger.

[20] Ibrahim, M. N. M., and Zemmelink, G. 2000. “A Comparative Evaluation of Integrated Farm Models with the Village Situation in the Forest-Garden Area of Kandy, Sri Lanka.” Asian-Australasian J. Anim. Sci. 13 (1): 53-9.

[21] Sattar, A., Mirza, R. H., and Ahmad, I. 2004. "Reproductive Efficiency of Jersey Cows under Subtropical Conditions of the Punjab.” Pakistan Vet. J. 24 (3): 129-33.

[22] Shrestha, S. L., and Sherchand, L. 1997. Genetic Improvement of Cattle, Buffalo and Small Ruminants in
Nepal: Requirements and Past Experiences. Breeding Programs for Ruminants in Asia, March 32-April 4, 1997, Kandalama (Matale), Sri Lanka.

[23] Kollalpitiya, K. M. P. M. B., Premaratne, S., and Peiris, B. L. 2012. "Reproductive and Productive Performance of Up-Country Exotic Dairy Cattle Breeds of Sri Lanka.” Tropical Agricultural Research 23 (4): 319-26.

[24] Rafique, M., Chaudhry, M. Z., and Amer, M. A. 2000. "Reproductive Performance of inter se Holstein Friesian × Sahiwal Crossbreds.” Pakistan Vet. J. 20 (3): 109-12.

[25] Lemma, H., Belihu, K., and Sheferaw, D. 2010. "Study on the Reproductive Performance of Jersey Cows at Wolaita Sodo Dairy Farm, Southern Ethiopia.” Ethiopian Veterinary Journal 14 (1): 53-70.

[26] Rokonuzzaman, M., Hassan, M. R., Islamand, S., and Sultana, S. 2009. "Productive and Reproductive Performance of Crossbred and Indigenous Dairy Cows under Smallholder Farming System.” J. Bangladesh Agril. Univ. 7 (1): 69-72.

[27] Lateef, M., Gondal, K. Z., Younas, M., Sarwar, M., Mustafa, M. I., and Bashir, M. K. 2008. "Milk Production Potential of Pure Bred Holstein Friesian and Jersey Cows in Subtropical Environment of Pakistan.” Pakistan Vet. J. 28 (1): 9-12.

[28] Ahmad, B., Khan, S., Manan, A., and Abdullah. 2007. "Production and Reproduction Performance of Jersey Cattle at Cattle Breeding and Dairy Farm Harichand Charsadda NWFP." Journal of Agricultural and Biological Science 2 (1): 3-4.

[29] Haq, A. U., Chaudhry, R. A., Rahil, T., Ahmad, N., and Jabbar, R. A. 1993. Reproductive Efficiency of Holstein Friesian and Jersey Cows Maintained at Livestock Experiment Station, Bhunikey (Pattoki), Punjab. Annual Report, Research Institute for Physiology of Animal Reproduction, Bhunikey (Pattoki), District Kasur.

[30] Prendiville, R., Shalloo, L., Pierce, K. M., and Buckley, F. 2011. "Comparative Performance and Economic Appraisal of Holstein-Friesian, Jersey and Jersey $\times$ Holstein-Friesian Cows under Seasonal Pasture-Based Management.” Irish Journal of Agricultural and Food Research 50 (2): 123-40.

[31] Mangurkar, B. R., Gokale, S. B., Shidey D. N., and Phadnis, Y. P. 1985. "Reproduction Performance of Holstein and Jersey Purebred Cows in a Herd in India.” Indian J. of Animal Sci. 55 (10): 893-7.

[32] Garcia, M., and Velez, M. 1988. "Factors Affecting the Production of Purebred and Crossbred Dairy Cows at the Panamerican Agricultural College.” Ceiba 29: 77-92.

[33] Haque, M. N., Haque, M. R., Parvin, A., and Hussain, M. M. 2011. "Productive and Reproductive Performance of Different Crossbred Cattle at Sylhet Government Dairy Farm.” Progress. Agric. 22 (1-2): 47-54. 